\title{
An Early Byzantine Alkali Glazing Tradition? Discussion of P. Armstrong (2020) The earliest glazed ceramics in Constantinople: A regional or international phenomenon? Journal of Archaeological Science: Reports, 29, 102078.
}

\author{
Ian C Freestone \\ UCL Institute of Archaeology \\ 31-34 Gordon Square \\ London WC1B 3DG \\ United Kingdom \\ i.freestone@ucl.ac.uk
}

\begin{abstract}
The suggestion by Armstrong (2020) that the ceramics from the fifth century monastery of St. Lot, Jordan, represent evidence for an early Byzantine alkali glazing tradition is based upon a misinterpretation of an earlier study by Freestone et al. (2001). The St. Lot glazes were unintentional and formed as a result of the reaction of the kiln vapour with the clay ceramic. Evidence for an early Byzantine alkali glazing technology is called into question.
\end{abstract}

Keywords: Byzantine, ceramic, glaze, composition, Monastery of St. Lot, Deir 'Ain 'Abata, Jordan

\section{Introduction}

Lead glazes are generally considered characteristic of Byzantine ceramic production.

However, Pamela Armstrong (2020) draws attention to the use of alkali (soda-rich) glazes on tenth century Byzantine polychrome white wares considered to have been made in Constantinople, and analysed by previous authors (Vogt and Bouquillon 1996, Vogt et al. 1997 and Lauffenburger et al. 2001). She suggests that there may have been a preceding tradition of the use of alkali glazes in the Byzantine world which has not been recognised due to lack of archaeometric investigation. She speculates that alkali glazes were experimented with at an early stage but rejected in favour of lead-based glazes and calls for more analytical work on to investigate the use of alkali glazes on Byzantine pottery. Here, the evidence presented for such an earlier tradition is called into question.

Our work on the fifth century glazed pottery of the Monastery of St. Lot (Deir 'Ain 'Abata), Jordan (Freestone et al. 2001), is cited by Armstrong (op. cit.) as evidence for the use of lead-free alkali-fluxed glazes by Byzantine potters. She draws a parallel between the sodarich glazes of the St. Lot pottery and the use of alkali fluxes to produce turquoise glazes on Byzantine Polychrome White Ware. She correctly states that we concluded that production of the alkali glazes at St. Lot was accidental, but dismisses this conclusion, suggesting that we argued for it "on the basis that Byzantine potters did not use alkali glazes". This is an argument that we did not use and represents a serious misunderstanding and misrepresentation of our paper. Our interpretation was based upon the materials analysis 
of the St. Lot pottery. The purpose of this note is to explain why there is no direct relationship between the St. Lot glazes and the polychrome white wares of tenth century Constantinople. Neither are they directly related to the near eastern alkali glazing tradition, which is common in ceramics of the first millennium C.E. such as the widespread turquoise glazed wares of the Sasanian and Islamic worlds.

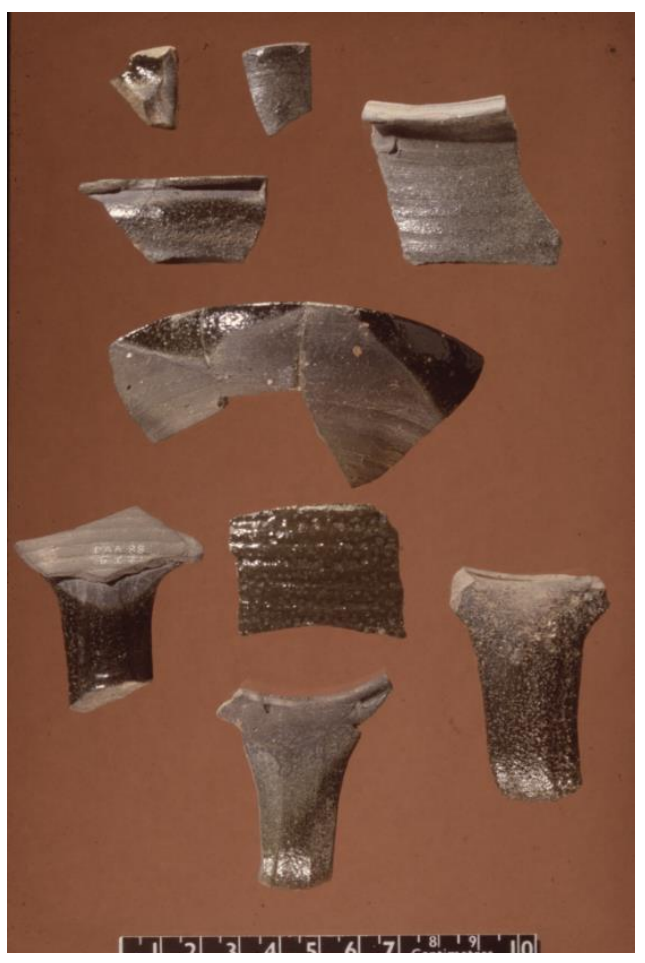

Fig. 1. Glazed sherds from the Monastery of St. Lot, Deir 'Ain 'Abata, Jordan.

\section{The ceramics of St. Lot, Jordan}

Examples of the St Lot glazed ceramics are given in Fig. 1 (in colour on-line), which shows the character and distribution of the glaze on the ceramic bodies. In fact, sherds with evidence of glaze represent a very small percentage of the total number of sherds in the same fabric retrieved from the site. They comprise dark green glazes over hard grey to brown bodies. The glazes are patchy and do not often completely cover the surface of a single sherd. They frequently appear rough and uneven, unlike the smooth surfaces of the alkaline glazed wares of the Islamic world. Scanning electron microscopy reveals the glazes to be thin; while they may be up to $0.1 \mathrm{~mm}$ thick, they are frequently only a few micrometres. The bodies are non-calcareous and vitrified. The firing temperatures were estimated to be in the range $1000^{\circ} \mathrm{C}-1150^{\circ} \mathrm{C}$ on the basis of refiring experiments and SEM examination (Freestone et al., op. cit.). These characteristics clearly differ from the typical alkaline glazed wares of the Middle East which are found on calcareous clay or stonepaste bodies, fired in the range $850-1000^{\circ} \mathrm{C}$, with glazes of around or in excess of $200 \mu \mathrm{m}$ thick (e.g. Mason et al. 2001, Paynter 2009, Tite et al. 2011).

The key to the origins of the St Lot glazes is found in their compositions. Table 1 shows that, although fluxed by the oxides of sodium and potassium, the St Lot glazes contain 
exceptionally high alumina, around $10 \%$ or more, along with high titanium and iron oxides. The alumina contents of Islamic alkali glazes are less than $3 \%$, and frequently below $1 \%$ (e.g. Mason et al., op. cit.). The St Lot glazes formed by a reaction between alkali flux and clay. Our interpretation was that the glazes on the St Lot pottery were formed as a reaction between fuel ash carried into the kiln chamber in particulate or vapour form, and the clay body of the ceramic. This is fully consistent with the sparse occurrence of glazed ware in the overall ceramic assemblage, the thin character and sporadic distribution of glazes on an individual vessel and the firing temperatures of the wares, which are high relative to most middle eastern pottery of the period. The glazes formed as a consequence of the kiln architecture, the fuel used and the high firing temperatures, and their distribution suggests that they were not intentionally made by applying the flux to the surface of the vessels. As parallels, we can look to the early development of Rhenish glazed stoneware, and perhaps more pertinent in the light of recent work, the early ash-glazed wares of South China, which also seem to have developed out of incidental reactions between fuel ash and body (Rehren and Yin 2012).

\begin{tabular}{|ccccc|}
\hline Sample & $41975 Z$ & $41976 \mathrm{X}$ & $41977 \mathrm{~V}$ & $41978 \mathrm{~T}$ \\
$\mathrm{SiO}_{2}$ & 56.0 & 56.0 & 61.3 & 68.3 \\
$\mathrm{TiO}_{2}$ & 1.2 & 1.2 & 1.0 & 0.6 \\
$\mathrm{Al}_{2} \mathrm{O}_{3}$ & 19.6 & 13.2 & 11.2 & 10.1 \\
$\mathrm{FeO}$ & 4.0 & 3.8 & 4.3 & 3.3 \\
$\mathrm{MgO}$ & 1.1 & 1.5 & 1.2 & 1.0 \\
$\mathrm{CaO}$ & 1.7 & 4.2 & 4.3 & 1.6 \\
$\mathrm{Na}_{2} \mathrm{O}$ & 10.4 & 15.3 & 10.4 & 9.4 \\
$\mathrm{~K}_{2} \mathrm{O}$ & 5.9 & 4.1 & 5.4 & 5.6 \\
\hline
\end{tabular}

Table 1. Compositions of ceramic glazes from the Monastery of St. Lot (Freestone et al. 2001).

\section{Discussion and Conclusion}

There is abundant evidence for the use of lead glazes across the late Roman and Byzantine worlds (Capelli et al., 2009, 2010, Damjanović et al. 2014, Waksman et al 2007, 2008, Walton and Tite 2010). The St. Lot glazes differ from these particularly in that they were fluxed by soda, rather than lead oxide. However, these sodic glazes also differ significantly in appearance, distribution, morphology, firing temperature and composition from sodiumrich glazes in the near eastern tradition. The latter were formed at lower temperatures by coating the ceramic body with a glass frit or mixture of quartz and sodic plant ash which was low in alumina, iron and titanium (Paynter 2009). As has been argued here, the material characteristics of the St Lot glazes strongly suggest that they were incidental products of the firing technology and do not represent the intentional use of soda as a flux. It is concluded that the St. Lot ceramics have no link to the alkali glaze tradition of the Middle East and do not represent evidence of the use of such an alkali glaze technology by Byzantine potters. 
The use of the St. Lot glazes as a key piece of evidence to support the early use of alkali glazes by Byzantine potters cannot be sustained. Even if these glazes had been intended by the potters and produced in a controlled way, the fact that they are vapour glazes would place them in a completely separate technological tradition to near eastern alkali glazed wares. This draws attention to the important point that it is not similarities in chemical composition that demonstrate direct technological connections between artefacts, but similarities in how they were produced, or their chaînes opératoires. For the same reason, the other example given of an early Byzantine alkali glaze, the 4th to 7th century glazed ceramics from Kharga Oasis, Egypt (Armstrong op. cit., Fig. 2), is also unlikely to be relevant as, on the basis of the colour and erosion of the bodies relative to the glaze these are faience (powdered quartz) bodies. Thus it appears that they were made in the Egyptian faience technological tradition rather than in the tradition of near eastern alkali glazed earthenware.

Turning to the alkali glazes on the $10^{\text {th }}$ century Byzantine polychrome white wares, many of these are clearly soda-rich, although they also contain substantial amounts of lead oxide (Vogt and Bouquillon op. cit., Lauffenburger et al., op. cit.). A sodium-rich material was clearly added to help flux the glaze. However, they appear to differ from the glazes of many Islamic ceramics in their relatively low magnesia and potash contents which, even when corrected for dilution by the lead in the glaze, are frequently around or less than $2 \%$, which is marginal in terms of the generally accepted boundary between natron and plant ash compositions. This raises the possibility of another alkali source. The alkali springs of Western Anatolia are now recognised as an important source of the alkali in Byzantine and Islamic glass found in Turkey (Schibille 2011, Rehren et al. 2015, Swan et al. 2018) and also were the source of the alkali used in the glazes of Iznik ceramics (Tite et al. 2015) and possibly the preceding Miletus ware (Burlot et al. 2020). There are abundant deposits of white-firing kaolinitic clay in the same region (e.g. Lauffenburger et al. op. cit.). The polychrome white wares may therefore represent a significant step in the use of regional raw materials in ceramic glazes. Hence, although the early date proposed by Armstrong for the use of alkali glazes on Byzantine pottery is not supported by current evidence, there is indeed a need for further research into the use of alkalis in later Byzantine ceramic technology.

\section{Acknowledgement}

I am very grateful to a referee for their helpful comments.

\section{References}

Armstrong, P., 2020. The earliest glazed ceramics in Constantinople: A regional or international phenomenon? Journal of Archaeological Science: Reports, 29, p.102078.

Burlot, J., Waksman, S.Y., Bellot-Gurlet, L. and Franci, G.S., 2020. The glaze production technology of an early Ottoman pottery (mid-14th (?)-16th century): The case of 'Miletus Ware'. Journal of Archaeological Science: Reports, 29, p.102073. 
Capelli, C., Cabella, R., Piazza, M., 2009. The Late Roman glazed pottery production in Eastern Alpine area and Danubian provinces: archaeometric analyses on fabrics and glazes, in C. Magrini, F. Sbarra (eds.), Late Roman glazed pottery productions in Eastern Alpine Area and Danubian Provinces. First results of an international project, Proceedings of the First International Meeting of Archaeology in Carlino (Carlino 14-15 December 2007), Campoformido, pp. 71-82.

Capelli, C., Cabella, R., Piazza, M., 2010. New archaeometric data on late Roman glazed pottery. Case-studies from Savaria (Hungary) and Rousse (Bulgary), in C. Magrini, F. Sbarra (eds.), Late Roman Glazed Pottery in Carlino and in Central-East Europe. Production, Function and Distribution. Proceedings of the Second International Meeting of Archaeology in Carlino (March 2009), BAR International Series 2068, Oxford, pp. 33-38.

Damjanović, L., Bikić, V., Šarić, K., Erić, S., Holclajtner-Antunović, I., 2014. Characterization of the early Byzantine pottery from Caričin Grad (South Serbia) in terms of composition and firing temperature, Journal of Archaeological Science 46(1), pp. 156-172.

Freestone, I., Politis, K.D., Stapleton, C.P., 2001. The Byzantine Glazed Pottery from Deir'Ain 'Abata, Jordan, in Villeneuve, E. and Watson, P.M., (Eds.), Colloquium on Byzantine and Early Islamic Ceramics in Syria-Jordan (IVth-VIIIth Centuries) [3-5 December 1994, Amman], Beirut, pp. 197-205.

Lauffenburger, J.A., Vogt, C., Bouquillon, A. 2001. Technical Insights into the Working Practices of the Byzantine Tile Maker in Gerstel, S.E.J. Lauffenburger, J.A. (Eds.), A Lost Art Rediscovered. The Architectural Ceramics of Byzantium, Pennsylvania, pp. 67-88.

Mason, R.B., Tite, M.S., Paynter, S. and Salter, C., 2001. Advances in polychrome ceramics in the Islamic world of the 12th century AD. Archaeometry, 43(2), pp.191-209.

Paynter, S., 2009. Links between glazes and glass in mid-2nd millennium BC Mesopotamia and Egypt. A.J. Shortland, I. Freestone, Th. Rehren (Eds.), From Mine to Microscope: Advances in the Study of Ancient Technology, Oxbow Books, Oxford (2009), pp. 93-108

Rehren, T., Connolly, P., Schibille, N. and Schwarzer, H., 2015. Changes in glass consumption in Pergamon (Turkey) from Hellenistic to late Byzantine and Islamic times. Journal of Archaeological Science, 55, pp.266-279.

Rehren, T. and Yin, M., 2012. Melt formation in lime-rich proto-porcelain glazes. Journal of Archaeological Science, 39(9), pp.2969-2983.

Schibille, N., 2011. Late Byzantine mineral soda high alumina glasses from Asia Minor: a new primary glass production group. PLoS One, 6(4).

Swan, C.M., Rehren, T., Dussubieux, L. and Eger, A.A., 2018. High-boron and High-alumina Middle Byzantine (10th-12th Century CE) Glass Bracelets: A Western Anatolian Glass Industry. Archaeometry, 60(2), pp.207-232. 
Tite, M.S., Shortland, A.J., Schibille, N. and Degryse, P., 2016. New Data on the Soda Flux Used in the Production of Iznik Glazes and Byzantine Glasses. Archaeometry, 58(1), pp.5767.

Tite, M.S., Wolf, S. and Mason, R.B., 2011. The technological development of stonepaste ceramics from the Islamic Middle East. Journal of Archaeological Science, 38(3), pp.570-580.

Vogt, C., Bouquillon, A., 1996. Technologie des plaques murales décorées de Preslav et de Constantinople (IXe-Xle siècles), Cahiers archéologiques 44, pp. 105-116.

Vogt, C., Bouquillon, A., Dubus, M., Querré, G., 1997. Glazed wall tiles of Constantinople: physical and chemical characterization, manufacturing, and decorative processes, in $\mathrm{H}$. Maguire (ed.), Materials Analysis of Byzantine Pottery, Washington D.C., 151-165 (1997).

Waksman, S.Y., Bouquillon, A., Cantin, N., Katona, I., 2007. The first Byzantine "Glazed White Wares" in the early medieval technological context, in S.Y. Waksman (ed.), Archaeometric and Archaeological Approaches to Ceramics, BAR International Series S1691, pp. 129-135.

Waksman, S.Y., Bouquillon, A., Cantin, N., Katona, I., 2008. Approche archéométrique des premières "Byzantine Glazed White Ware" et de productions glaçurées romaines et romaines tardives, Rei Cretariae Romanae Fautorum Acta 40, pp. 531-536.

Walton, M.S., Tite, M.S., 2010. Production technology of roman lead-glazed pottery and its continuance into late antiquity, Archaeometry 52(5), pp. 733-759. 